\title{
Move away from BITs framework: A need for multilateral investment treaty?
}

\author{
Malebakeng Agnes Forere \\ Senior Lecturer \\ University of Witwatersrand, Johannesburg \\ malebakeng.forere2@wits.ac.za
}

The objective of this paper is to critically evaluate the desirability of multilateral treaty that will take into account the needs of developed and developing countries alike as developed nations seek to protect their investment abroad while developing nations want to attract investment, be able to regulate and most importantly they want to limit access to international arbitration. In achieving this objective, the paper will give a snapshot of recent developments indicating a shift away from BITs framework, international investment arbitration and what was considered customary international law of investment. Following from these highlights, the paper will then consider the need of multilateral investment treaty against the current developments. Further, the paper will then discuss how such a multilateral treaty should look like in order to get a buy-in from both the developed and developing nations.

Research for this paper was funded by the Swiss State Secretariat for Economic Affairs under the SECO / WTI Academic Cooperation Project, based at the World Trade Institute of the University of Bern, Switzerland.

SECO working papers are preliminary documents posted on the WTI website (www.wti.org) and widely circulated to stimulate discussion and critical comment. These papers have not been formally edited. Citations should refer to a "SECO / WTI Academic Cooperation Project" paper with appropriate reference made to the author(s).

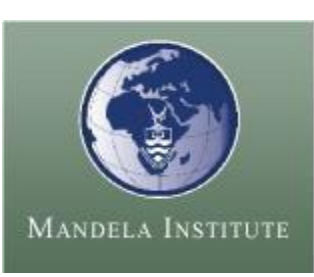




\title{
Move away from BITs framework: A need for multilateral investment treaty?
}

\author{
Malebakeng Agnes Forere*
}

\section{INTRODUCTION}

The principle of the obligation of a host state to protect foreign property can be traced back to Chorzow Factory case where the Permanent Court of International Justice (PCIJ) ruled that expropriation derogates from international law and that in the case of expropriation, the host state must ensure adequate and prompt compensation. ${ }^{1}$ Later, the rules on prompt and adequate compensation were to be explained further during the era of Mexican expropriations when the American Secretary of State Cordell Hull wrote to his Mexican counterpart that 'no government is entitled to expropriate private property, for whatever purpose, without provision for prompt, adequate, and effective payment therefor.' ${ }^{2}$ This rule on 'prompt, adequate and effective' compensation became known as the Hull Rule. Developing countries subsequently rejected the Hull rule for being too stringent although international arbitral tribunals continued to make awards on the basis of this rule. As a result, states could not know, with certainty, the applicable rules regulating compensation. ${ }^{3}$ To that end, developed nations resorted to bilateral investment treaties (BITs) since what was considered by them to constitute customary international law had been perpetually denied by developing countries.

Surprisingly, developing countries joined the BIT-spree as well in the 1990s and ultimately both developed and developing countries concluded BITs at unprecedented levels but for different reasons. In particular, a study undertaken by the United Nations Conference on Trade and Development (UNCTAD) in 1998 indicated that during the mid-nineties, motivation for developing countries to conclude BITs was to attract investment while motivation for developed economies was to seek protection. ${ }^{4}$ These divergent motivations are still applicable even in the $21^{\text {st }}$ century - they have not changed although the developing countries want to get protection against investors while attracting investment, unlike in the past where host states did not leave any policy space to regulate. Consequently, it remains an open question whether developing countries can introduce tighter rules regulating foreign investment and be able to attract investment at the same time.

\footnotetext{
*BA Law, LL.B (Lesotho); LL.M (Essex); PhD (Bern). Senior Lecturer in Law, University of the Witwatersrand.

${ }^{1}$ Case Concerning the Factory at Chorzów, Germany v Poland 1927 P.C.I.J. (ser. A) No. 9 (July 26), para 58.

${ }^{2}$ Green Hackworth Digest of International Law (1942) 655-665.

3 Cai Congyan, 'International Investment Treaties and the Formation, Application and Transformation of Customary International Law Rules’ (2008) 7 Chinese J. Int'l L. 3, 667.
}

${ }^{4}$ UNCTAD Bilateral Investments Treaties in the Mid 1990s (1998) at 8 
Nevertheless, as much as BITs are concluded across continents, they are similar with regard to standards of protection, and it can be argued that through BITs states have developed customary international law regarding the standards of protection. Despite BITs containing similar or same standards of protection, international community has not succeeded to adopt a multilateral treaty other than the International Convention on Settlement of Investment Disputes (ICSID), which as the name connotes only deals with rules governing settlement of investor-state disputes. The manner in which ICSID settles disputes and the award rendered by ICSID has been a subject of much debate in international investment law, ${ }^{5}$ and some countries especially in Latin America such as Bolivia have responded to ICSID's deficits by pulling out of ICSID. In addition, a recent research that I was part of, which focuses on investment policy and regulation in Australia, Brazil, Chile, China, India and South Africa, indicates that countries have undertaken a journey to reflect on their BITs policy framework and have thus made or proposed changes in their respective investment law. For instance, South Africa passed Protection of Investment Act which significantly reformulates standards of protection but most importantly introduces a rule of exhaustion of local remedies before international investment arbitration can be resorted to, and this seems to be a trend with other countries as well. ${ }^{6}$ Further, in the event that parties finally have to resort to international arbitration, South Africa has done away with investor-state dispute settlement mechanism and introduced state-state settlement mechanism.

From the afore-going, it follows that the investment climate has become unpredictable and cumbersome as investors now have to deal with national laws and national courts. Consequently, the debate on whether a multilateral treaty has to be adopted cannot be avoided. As a result, the objective of this paper is to critically evaluate the desirability of multilateral treaty that will take into account the needs of developed and developing countries alike as indicated earlier that developed nations seek to protect their investment abroad while developing nations want to attract investment, be able to regulate and most importantly they want to limit international arbitration excesses. In achieving this objective, the paper will give a snapshot of recent developments indicating a shift away from BITs framework, international investment arbitration and what was considered customary international law of investment. Following from these highlights, the paper will then consider the need of multilateral investment treaty against the current developments. Further, the paper will then discuss how such a multilateral treaty should look like in order to get a buy-in from both the developed and developing nations, and finally concludes.

\footnotetext{
${ }^{5}$ OK Fauchald, "The Legal Reasoning of ICSID Tribunals - An Empirical Analysis" (2008) European J of Int Law; J Alvarez, K Khamsi "The Argentine crisis and foreign investors: a glimpse into the heart of the investment regime" (2008) Yearbook on International Law and Policy

${ }^{6}$ C Schreuer, "Calvo's Grandchildren: The Return of Local Remedies in Investment Arbitration" (2005) The Law and Practice of International Courts and Tribunals
} 


\section{STANDARDS OF PROTECTION UNDER BITs}

Developing countries have traditionally been rule-takers especially in trade and investment platforms given their desperation for FDI (except that developed nations are equally in need of FDI). As the rules were made by developed nations in a form of BITs which developing countries agreed to in their relations with industrialized nations and as between developing countries, this section will focus on the older BITs concluded by the United States, Germany, Switzerland and United Kingdom as representative of Western European countries and Japan. This work will not concern itself with the analysis of Model BITs such as NAFTA or OECD or United States Model BIT because model BITS are a new phenomenon which many BITs were not concluded using such templates (model BITs). The discussion will be limited to right of admission and establishment and conditions therefore, standards of protection, expropriation and dispute settlement.

\section{Admission and Establishment}

Under international law, there is no obligation of states to admit foreign investment - it is left up to states parties to decide which investment to admit or reject, ${ }^{7}$ and this is the position that is adopted by BITs. No state has liberalized its economy to foreign investors; even the most advanced and largest economies in the world such as the United States have not opened up their domestic markets fully. Typical language found in BITs is as follows:

'Each Contracting Party shall in its territory promote as far as possible investments by investors of the other Contracting State and admit such investments in accordance with its legislations. ${ }^{8}$

Among BITs, NAFTA remains the only exception in this regard that provides for right of establishment (national treatment for establishment), ${ }^{9}$ and it is questionable whether the rights of admission and establishment can be multilateralised. Specifically, the wording of NAFTA reads as follows:

'Each Party shall accord to investors of another Party treatment no less favorable than that it accords, in like circumstances, to its own investors with respect to the establishment, acquisition, expansion, management, conduct, operation, and sale or other disposition of investments. ${ }^{10}$ (italics for emphasis)

Nevertheless, where a treaty adopts the NAFTA right of establishment provision, it usually provides sectors which this provision does not apply, thus indicating the point made earlier that no country will liberalize its domestic market for foreign investors fully.

\footnotetext{
${ }^{7}$ Rudolph Dolzer and Christoph Schreuer, Principles of International Investment Law (Oxford University Press, 2008) 7 .

${ }^{9}$ NAFTA Chapter 11, Article 1102.

${ }^{10}$ NAFTA Chapter 11, Article 1102.
} 
It is at the stage of admission and establishment that host states get to screen investments and impose the conditions under which foreign investment is allowed in the host country. Such conditions come in a form of investment measures which are usually a combination of incentives to attract investment and performance requirements to address economic development of a host state, including addressing anticompetitive practices of the investor. ${ }^{11}$ Performance requirements may be imposed as entry requirements, that is, conditions that investor must meet for acceptance or they may be imposed as operational requirements, that is, conditions for establishment and/or maintenance of investment. ${ }^{12}$ Examples of performance requirements are local content requirements (geared to improve local business specifically procurement of goods and services), export requirements (geared to improve the host balance of payments) and transfer of technology. ${ }^{13}$ Often, investors are given incentives to comply with these requirements - for example, tax reductions or direct capital, which can be argued to violate Subsidies Agreement because they are intended for export goods and never apply to imports. ${ }^{14}$ Nevertheless, performance requirements have since been recognized as important for host countries as reflected in Article XXII of the Havana Charter:

(c) without prejudice to existing international agreements to which Members are parties, a Member has the right:

(ii) to determine whether and, to what extent and upon what terms it will allow future foreign investment;

(iv) to prescribe and give effect to other reasonable requirements with respect to existing and future investments; ${ }^{15}$

Since the failed Havana Charter, investment measures were first addressed in the GATT/WTO during the Uruguay Round. As GATT only deals with trade liberalization, it was made clear throughout the GATT Uruguay Round negotiations that only investment measures that distort free trade will be covered and therefore an agreement that addresses investment barriers to trade was negotiated. ${ }^{16}$ It follows therefore that this agreement does not

\footnotetext{
${ }^{11}$ Edmund M.A. Kwaw, Trade Related Investment Measures in the Uruguay Round: Towards a GATT For Investment? 16 N.C.J. INT'L L. \& COM. REG (1991) 309-349, 318.

12 Edmund M.A. Kwaw, Trade Related Investment Measures in the Uruguay Round: Towards a GATT For Investment? 16 N.C.J. INT'L L. \& COM. REG (1991) 309-349, 318.

13 Aware of the importance of transfer to technology to developing countries, the international community sought to develop a code of conduct but it failed: U.N. Conference on an International Code of Conduct on the Transfer of Technology, Draft International Code Of Conduct on the Transfer Of Technology, U.N. Doc. TD/Code TOT/25, U.N. Sales No. GE.80-53826 (1980). To this end, Sauvant discusses the reason why such a noble initiative failed and how it can shape future discussions for the law regulating foreign investment, see Karl Sauvant, 'The Negotiations of the United Nations Code of Conduct on Transnational Corporations: Experience and Lessons Learned', 16 J World Investment and Trade (2015) 11-87.

${ }^{14}$ Todd S. Shenkin, Trade-Related Measures in Bilateral Investment Treaties and the GATT: Moving Toward a Multilateral Investment Treaty 55 U. Pitt. L. Rev 541 (1994) 541-606,551.

${ }_{15}^{15}$ Havana Charter, Chapter II, Article XXII.1(c)(ii) and (iv).

${ }^{16}$ Edmund M.A. Kwaw, Trade Related Investment Measures in the Uruguay Round: Towards a GATT For Investment? 16 N.C.J. INT'L L. \& COM. REG (1991) 309-349, 311.
} 
seek to eliminate investment barriers but addresses those barriers to trade that are caused by investment measures. Specifically, the scope of coverage limits investment measures to those violating Article III (national treatment) and XI (quantitative restrictions) of the GATT. ${ }^{17}$ Examples of prohibited investment measures are: local content requirements, import quota, export requirements. ${ }^{18}$ Interestingly, most countries adopt performance requirements for foreign investors and not applicable to local investors thereby violating Article III of the GATT. Looking at the WTO Trade-Related Investment Measures (TRIMs) provisions referred to above, this Agreement does not regulate all aspects on investment measures, and it simply prohibits the use of investment measures that distort trade flows.

Many BITs are silent on performance requirements but the BITs concluded by the United States and Canada specifically prohibit the use of performance requirements.

It is important to note that developed countries use incentives more than developing nations to attract investment while developing countries use a bit of both, that is incentives in a form of tax deductions and low labour and environmental standards and largely performance requirements. This does not mean that developed nations do not use performance requirement; developed nations mask performance requirements under the umbrella of rules of origin. ${ }^{19}$

\section{Standards of protection or treatment}

During the early years of independence, developing countries were keen to have control and ownership of their resources and this saw the rate of expropriations rising upwardly. Consequently, capital exporting countries sought to protect their investors abroad through "exceptionally" stringent bilateral investment treaties, ${ }^{20}$ which still continue even today. Over and above clauses on expropriations, BITs embody the standard of treatment, which host states promise to investors. Such standards commonly include national treatment and most favored nation (MFN), full protection and security, and fair and equitable treatment discussed below.

a) National treatment and most favoured nation

National treatment and most favoured nation treatment have been the hallmark of all investment treaties. The prohibition against discrimination on the basis of nationality extends to both de jure and de facto discrimination in most BITs. It is in all BITs.

\footnotetext{
${ }^{17}$ Agreement on Trade-Related Investment Measures, Article 2.

18 Annex to the Agreement on Trade-Related Investment Measures.

19 United Nations, The Impact of Trade-Related Investment Measures on Trade and Investment: Theory, Evidence and Policy Implications (United Nations, 1991) 3.

${ }^{20}$ Jurgen Kurtz, 'A General Investment Agreement in the WTO? Lessons from Chapter 11 of NAFTA and the OECD Multilateral Agreement on Investment,' 23(4) U. Pa. J. Int'l Econ. L (2014) 713-789, 720.
} 
The common language used for national treatment and MFN treatment goes as thus:

'Neither Contracting State shall subject investments in its own territory owned or controlled by investors of the other Contracting State to treatment less favourable than it accords to investments of its own investors or to investments of investors of any third State. $^{, 21}$

What has remained thorny is the importation of other BITs standards including dispute settlement, with some BITs excluding it from MFN while others which did not exclude it find themselves embroiled in disputes that import certain provisions on dispute settlement from other BITs. $^{22}$

b) Full protection and security

This is an absolute standard of protection, dependent only on international law, which requires states to take positive steps to protect physical property which is the subject of investment. ${ }^{23}$ Full protection and security is different from 'protection and security' under customary international law for the latter is limited to physical protection while the former extends to other spheres. ${ }^{24}$ Thus, 'full protection and security' extends to legal security as well. $^{25}$ Some have argued that breadth of this standard covers economic regulatory powers which have the effect of impairing the management, maintenance, use, enjoyment or disposal of investment. ${ }^{26}$ Such protection is not only limited to organs of state but extends to acts of private parties. ${ }^{27}$ Under this obligation, states parties undertake not to impair the management, maintenance, use, enjoyment or disposal by unreasonable or discriminatory means.

The full protection and security treatment is sometimes referred to as "the most constant protection and security", but irrespective of whether it is referred to as "full protection and

\footnotetext{
${ }^{21}$ See Germany - Afghanistan BIT 2007, Art. 3.

${ }^{22}$ Emilio Agustin Maffezini v Kingdom of Spain ICSID Case No ARB/02/08, 3 August 2004; Y Radi, The Application of the Most Favoured Nation Clause to the Dispute Settlement Provisions of Bilateral Investment Treaties: Domesticating the Trojan Horse 18 European Journal of International Law (2007) 757

${ }^{23}$ In Saluka Investments BV v The Czech Republic, partial Award 17 March 2006 at para484, the Tribunal ruled that "the 'full protection and security' clause ... protect[s] more specifically the physical integrity of an investment against interference by use of force."

${ }^{2424}$ Azurix v The Argentine Republic, Award 14 July 2006, para 408.

${ }^{25}$ Saluka Investments BV v The Czech Republic, partial Award 17 March 2006 at paras 483-484.

${ }^{26}$ Christoph Schreuer, 'Full Protection and Security', (2010) Journal of International Dispute Settlement, 1-17, 7 citing TW Walde, Energy Charter Treaty-based Investment Arbitration, 5 J World Investment and Trade (2004)

${ }^{27}$ WENA Hotels $v$ Egypt Award 8 December 2000 (2002) where the police failed to prevent seizure of the two hotels belonging to WENA (investor) by employees of EHC which is a state entity. The Tribunal found Egypt to have violated the provision on full protection and security because the state, through police and the army did nothing to prevent the seizure despite being aware of it being it happened.
} 
security" or "the most constant protection and security", the variations have no bearing on the kind of protection that is expected from the host state. ${ }^{28}$

c) Fair and equitable treatment

This treatment entails that host undertakes to refrain from engaging in any conduct that is or appears unfair and inequitable. Unfairness here does not relate to discrimination embodied in national treatment but looks at the treatment given to an investor without comparing it to the one accorded to nationals or investors from a third country, meaning, it is an absolute standard of treatment. It is one of the most litigated upon provisions, and it has no precise tenets. It is basically imprecise and vague. Nonetheless, it is a hallmark of investment treaties between developed and developing countries, ${ }^{29}$ treaties amongst developed countries, ${ }^{30}$ and treaties among developing countries. ${ }^{31}$ It was first introduced in the failed Havana Charter in $1948,{ }^{32}$ and it were to feature later in the early 1960s in the BITs yet it has attracted many cases in international tribunals. To this end, the study undertaken by indicated that in a period between 1997 and 2007 alone, there were 34 cases where violation of this standard was claimed. $^{33}$ This standard has known for:

'Being non-contingent upon other standards or situations, ... being so broad and vague, but also the fact that it is a unilateral obligation of the home State, requiring no specific duties from the Investor, had two direct consequences: first the Investors relied on FET extensively, seeing it as a sort of divine gift given to them by States and second, a lot of commentators and host States started to violently criticize this standard because of the unbalanced relationship it allegedly created between the foreign Investor and the host State. ${ }^{34}$

In the case confidential case between Swiss Investor and South Africa, the investor claimed violation of full protection and security treatment where the investment, which was not in use for a long period, was vandalized by local residents residing in the nearby locality. The Tribunal ruled that -

'full protection and security imposed a duty of due diligence or reasonable care by the State authorities and that such duty was breached vis-à-vis the Swiss investor by the fact of not having offered a sufficient level of police protection in the area where the

\footnotetext{
${ }^{28}$ Christoph Schreuer, 'Full Protection and Security', (2010) Journal of International Dispute Settlement, 1-17, 1.

30

31

32

${ }^{33}$ Ioana Tudor, The Fair and Equitable Treatment Standard in International Law of Foreign Investment (Oxford University Press, 2008) 3.

${ }^{34}$ Ioana Tudor, The Fair and Equitable Treatment Standard in International Law of Foreign Investment (Oxford University Press, 2008) 3-4.
} 
investment was located in order to prevent incursions, thefts, and vandalism perpetrated by residents of a nearby settlement. ${ }^{35}$

Interestingly, both full protection and security treatment and fair and equitable treatment are not available to the host national investors; both are the standards that host governments offered to foreign investors with a view to attract investment or imposed on host by home countries to safeguard the investments/investors from home countries.

There is always a question as to the relationship of fair and equitable treatment and full protection and security, this work will not go into that debate but adopts the conclusion made by Michael Schmid who noted that it is would be hard to understand why drafters continually have these two standards if there were no differences between them. ${ }^{36}$

The question surrounding the issue of these absolute standards of protection - fair and equitable treatment and full protection and security has always been whether it is the customary international law standard or the higher standard. For instance, the US Model BIT of 2004 limits these standards of protection to the customary international law standard which is regarded as the minimum standard. ${ }^{37}$

\section{Expropriation and compensation}

In light with state sovereignty, it is generally accepted that states have a right to take alien property; what becomes the subject of regulation by treaties is the procedural safeguards that must be followed when takings happen and the accompanying compensation thereof. ${ }^{38}$ Therefore, the provision on expropriations as contained in BITs and indeed under customary law prevents the host government from expropriating or nationalizing foreign investment except for public interest reasons and on a non-discriminatory basis, observing due process. Most importantly, where an investment has been expropriated, the host state has an obligation to pay compensation equivalent to the market value of the expropriated investment immediately before the date on which expropriation was known. Such compensation should be paid without delay at convertible currency.

Unlike the absolute standards of 'full protection and security' and 'fair and equitable treatment' discussed above, this is the oldest and feature of the law governing property of aliens in the host states, which has very clear features: expropriations for 1) public interest reasons and on a non-2) discriminatory basis, 3) observing due process, and 4) accompanied by prompt, adequate and effective compensation (fair market value).

The difficulty however lies with indirect expropriations or measures tantamount to expropriations or the so called creeping expropriations because there is a thin line between

\footnotetext{
35 Michael Schmid, Switzerland' in Chester Brown, Commentaries on Selected Model Investment Treaties (Oxford, 2013) 673.

${ }^{36}$ Michael Schmid, 'Switzerland' in Chester Brown, Commentaries on Selected Model Investment Treaties (Oxford, 2013) 672.

${ }^{37}$ US Model BIT 2004, Art 5.1.

${ }^{38}$ Walter Fletcher Smith case
} 
indirect expropriation and the government right to regulate. ${ }^{39}$ Often host countries have found themselves tied - the sovereign right to regulate stripped off by BITs and thus not being able to discharge the fundamental duty of states - the duty to regulate for public interest. Further, the investors are equally challenged by indirect expropriations as they are normally illegal in the sense that there is no compensation. ${ }^{40}$ Taking without compensation makes expropriation unlawful and therefore attracts state responsibility in a form of reparation (restitution and where impossible, monetary damages). ${ }^{41}$ Thus, international law requires that where an unlawful taking of property has occurred, ${ }^{42}$ it must be followed by restitution, that is, the owner of property must be returned to the position in which he was before the taking, if possible. ${ }^{43}$ If it is not possible, then monetary damages (reparation must be paid).

A typical provision on direct and indirect expropriations would read, in relevant parts, as thus:

'Neither of Contracting Parties shall take, either directly or indirectly, measures of expropriations or nationalization or any other measure having the same nature or an equivalent effect against investments belonging investors of the other Contracting Party, unless the measures are taken in the public interest, on a nondiscriminatory basis, under the due process of the law, and provided that provisions be made for effective and adequate compensation. ${ }^{44}$

For purposes of reparation however as shown above, international law does not draw a distinction between indirect expropriation and the governmental regulatory measure, and this has caused great concern as will be shown in the sections to follow.

\section{Dispute settlement}

Historically, investors relied on their home state for settlement of investment disputes because protection of individuals was a matter of obligations of states. ${ }^{45}$ Since the international courts or tribunals are for states, it follows that special institutions had to be

\footnotetext{
${ }^{39}$ The interface of bona fide governmental regulatory measure and indirect expropriation is well captured by Judge Rosalyn Higgins in her often quoted 1982 Hague Lecture when she remarked:

'Is this distinction intellectually viable? Is not the State in both cases (that is, either by a taking for a public purpose, or by regulating) purporting to act in the common good? And in each case has the owner of the property not suffered loss? Under international law standards, a regulation that amounted (by virtue of its scope and effect) to a taking, would need to be 'for a public purpose' (in the sense of a general, rather than for a private, interest). And just compensation would be due.

See, R Higgins, 'The Taking of Property by the State: Recent Developments in International Law,' 176 Recueil des Courts (1982-III) 259, 331.

${ }^{40}$ Rudolph Dolzer \& Christoph Schreuer, Principles of International Investment Law (Oxford University Press, 2008) 91-2.

${ }^{41}$ Francis J. Nicholson, The Protection of Foreign Property under Customary International Law 6(3) B.C.L. Rev. (1965) 391-415.

${ }^{42}$ Unlawful taking can be one which is not sanctioned by law or one which goes against the undertaking not to expropriate in terms of the treaty.

${ }^{43}$ Francis J. Nicholson, The Protection of Foreign Property under Customary International Law 6(3) B.C.L. Rev. (1965) 391-415, 396-7.

${ }^{44}$ Switzerland - Poland BIT, Art. 6.1.

${ }^{45}$ Ioana Tudor, The Fair and Equitable Treatment Standard in International Law of Foreign Investment (Oxford University Press, 2008) 1.
} 
created in order to give investors standing to litigate investment disputes, and so ICSID was created in 1965 and others followed. Further, because states can claim sovereign immunity when being sued for expropriating the investment, host governments often bind themselves to international arbitration and this serves as a guarantee that there will be a judicial process by a neutral body and remedies will follow when disputes arise. ${ }^{46}$ ICSID has seen a flood of investment cases submitted to it, and it has been attacked for being skewed against host governments and towards investors in its awards, lack of transparency, inconsistent decisions, and hefty awards that potentially wipe out economies as it happened in Argentina. ${ }^{47}$ Consequently, some South American countries such as Bolivia and Venezuela have pulled out of it.

\section{SHIFTS IN THE STANDARDS OF PROTECTION}

Customary international law on the protection of investment as contained in BITs is being revised or rejected because it is seen as furthering the interests of colonialism at the expense of developing countries. ${ }^{48}$ This section of the essay looks at the shifts that have been made by certain countries such as South Africa, Brazil, India and Australia, in relevant parts.

\section{Admission and Establishment}

Many, if not all countries except in NAFTA, do not provide for the right of admission and establishment and there has not been any shift to the traditional approach that countries have always followed. Investment measures are still applicable and invoked by countries where necessary.

2. Standards of treatment or protection

a) National treatment and Most Favoured Nation

\footnotetext{
46 As far as international arbitration is concerned, investors seem to be focusing only on one aspect adjudication; yet sovereign immunity extends beyond adjudication to enforcement of arbitral awards. Thus, often investors are left with unenforceable arbitral awards because of sovereign immunity which is usually claimed by host states. Consequently, national courts are always needed to ensure finality of investment dispute. Nevertheless, dispute resolution by international tribunals is a key feature of BITs particularly because investors often do not have trust in the national judicial systems and they are comfortable with international tribunals over national courts. Of course, it is ironic that investors are uncomfortable with national courts yet enforcement of international arbitral awards rests with national courts. This is so because most host states do not willingly enforce the arbitral decisions; a bit of coercion is needed, and that can only be exerted by national courts. Therefore, the mistrust in the national courts of host states is neither here nor there. See, George K Foster, "Collecting From Sovereigns: The Current Legal framework for Enforcing Arbitral Awards and Court Judgments Against States and their Instrumentalities, and Some Proposals For Its Reform" (2008) 25 (3) Arizona J. of Int'l \& Comp. Law 668.
}

\footnotetext{
${ }^{47}$ Susan D. Franck, "The Legitimacy Crisis in Investment Treaty Arbitration: Privatizing Public International Law through Inconsistent Decisions," Fordham Law Review 73 (2005) 1521.

${ }^{48}$ Francis J. Nicholson, 'The Protection of Foreign Property under Customary International Law' 6(3) B.C.L. Rev. (1965) 391-415, 392.
} 
There has not been significant shift from national treatment from the way it has been applied. However, with regard to MFN and the trend of treaty importation in investment arbitration, countries are beginning to develop cold feet to MFN with India having excluded MFN altogether from its Model BIT of 2015 and South Africa excluding it from the Protection of Investment Act. Traditionally countries would list exceptions to MFN such on issues of taxation but now countries have rethought the impact of MFN on their economies.

b) Full protection and security and fair and equitable treatment

Like any country, South Africa concluded BITs that have fair and equitable treatment and full protection and security treatment. Equally, like many countries, South Africa faced litigation before ICSID Tribunal for violating these absolute standards of treatment - fair and equitable treatment and full protection and security.

Unhappy with the ICSID rulings, South African started a journey to not renew its BITs upon expiry, and adopted legislation - Protection of Investment Act (what can typical be regarded as a Model BIT for South Africa) - to lay standards of treatment and protection for foreign investment. The guarantee on full protection and security has been done away with in the Act and foreign investors are now guaranteed the same protection as that given to local investors to the extent that available resources and capacity allow. ${ }^{49}$ This means full protection and security can no longer be guaranteed and this could be very disturbing against the backdrop of protests that turn out to be violent and destructive of property in South Africa. It should be recalled that the Swiss Investor case against South Africa was based on the full protection and security provision found in Switzerland - South Africa BIT. This case was held in camera in accordance with the UNCITRAL Rules which permit states to conduct proceedings away from the public. The Swiss investor sued South Africa for failure to provide full protection and security. ${ }^{50}$ The claimant argued that South African police turned a blind eye to vandalism and theft orchestrated by residents of Acornhoek, which is a settlement near his property. The property was purchased by the investor with a view to constructing a game lodge and conference center. The South African government, in its defense, argued that as a developing state, the country does not have enough resources and as such there has to be flexibility in applying the Swiss - South Africa BIT. The tribunal ruled that states could escape liability under treaty provisions if they were allowed to raise a defense of lack of resources. ${ }^{51}$ Consequently, the tribunal found that there had been no adequate or effective policing over the property and those apprehended had not been prosecuted, which was contrary to the treaty obligation on the part of South Africa to provide full protection and security. ${ }^{52}$ South Africa was therefore found to have breached its treaty obligations and ordered to pay ZAR6.6m plus interest which is an equivalent of $\$ 441,671$. This amount is significantly high for a

\footnotetext{
${ }^{49}$ Protection of Investment Act, s 9.

${ }^{50}$ Luke Eric Peterson, 'Swiss investor prevailed in 2003 in confidential BIT arbitration over South Africa land dispute' IAReporter 22 October 2008, accessed May 27, 2016. http://www.iareporter.com/articles/swissinvestor-prevailed-in-2003-in-confidential-bit-arbitration-over-south-africa-land-dispute/. 
developing country and also for this type of breach especially because the investor had somehow not developed the property as yet.

Similarly, Chilean BITs had a provision on full protection and security but the "Chilean Model BIT" of 1994 no longer has this provision. ${ }^{53}$

The fair and equitable treatment has altogether been left out from the South African Protection of Investment Act as its flexible nature could not allow host states to get predictability that is required in law. ${ }^{54}$ India has also completely left out the fair and equitable standard from its Model BIT of 2015, and the trend now in India's BITs has been to leave out this standard as evidenced by India- Singapore BIT. ${ }^{55}$

\section{Expropriation}

The issue of property rights is very sensitive to developing countries because for the longest time their property was under the control of colonial masters and upon attainment of independence, states want to exert control over their natural resources yet these resources are now in the hands of foreign investors who are not too keen to let go. ${ }^{56}$ Because of the legacies of colonialization and apartheid in countries such as South Africa, governments are under pressure to regulate for public interest in order to ensure economic redistribution. Given the interface between indirect expropriation and legitimate governmental right to regulate, states have to pay a huge price for pursuing legitimate interests to address effects of colonialization and apartheid. Consequently, countries are beginning to reconsider their approach to expropriation especially indirect expropriation. Specifically, India has had delineate direct expropriation and indirect expropriations with the resultant effect of creating adequate policy space by excluding legitimate non-discriminatory regulatory measures from the purview of indirect expropriation in the India- China BIT. ${ }^{57}$

In South Africa, the Act does not even make reference to expropriation; rather, it guarantees investor's right to property in accordance with section 25 of the Constitution. Nevertheless since the Act incorporates section 25 of the Constitution, indirect expropriation are covered under section $25(1)$ as deprivation of property. Thus, the Constitution regulates both deprivation of property (section 25(1) of the Constitution) and expropriation (section 25(2) of the Constitution). The Constitution itself does not provide guidance on the differences

\footnotetext{
${ }^{53}$ United Nations Conference on Trade and Development (UNCTAD), 'Chile Model BIT' (Investment Policy Hub, 1994) <http://investmentpolicyhub.unctad.org/Download/TreatyFile/2841> accessed 19 September 2016.

${ }^{54}$ In Gami Investments Inc v. United Mexican States, Award, 44 ILM 545, 114 (Nov. 15, 2004), the Tribunal held that, 'the standard [of FET] is to some extent a flexible one which must be applied to the circumstances of each case.'

55 Comprehensive Economic Partnership Agreement, India- Singapore, done in New Delhi, June 29, 2005 [hereinafter India- Singapore CEPA 2005].

${ }^{56}$ Francis J. Nicholson, The Protection of Foreign Property under Customary International Law 6(3) B.C.L. Rev. (1965) 391-415, 392.

${ }^{57}$ India - China Agreement for the Promotion and Protection of Investment (2007), Art 5(3).
} 
between the two concepts but courts have clarified the differences between the two. ${ }^{58}$ In distinguishing between these two words, Nkabinde J in Reflect-All 1025 CC and Others $v$ MEC for Public Transport, Roads and Works, Gauteng Provincial Government and Another said:

Although it is trite that the Constitution and its attendant reform legislation must be interpreted purposively, courts should be cautious not to extend the meaning of expropriation to situations where the deprivation does not have the effect of the property being acquired by the state. It must be emphasised that section 10(3) does not transfer rights to the state. . . As I have said, the state has not acquired the applicants' land as envisaged in sections 25(2) and 25(3) of the Constitution. For that reason, no compensation need be paid. ${ }^{59}$

From the above quotation, deprivation of property entails personal sacrifices being made by property owners without compensation whereas expropriation entails acquisition of property by the state for reasons of public interest and with the payment of compensation. ${ }^{60}$ The determining factor seems to be whether the property has been acquired by the state and this is interpreted narrowly by the South African courts and not necessarily in accordance with international practice. ${ }^{61}$ To this effect, under international law, ${ }^{62}$ it is not required that the state should hold title to property in order for expropriation to have taken place. ${ }^{63}$ In South Africa, as long as the state does not have ownership to the property alleged to have been expropriated; an act of expropriation cannot be held to have occurred irrespective of the fact that the state has deprived the owner of possession, and control of access to the benefits and economic use of the property. ${ }^{64}$ Thus, where the state acquires property and passes it to third parties, this does not amount to expropriation according to South African law and no compensation need be paid. However this position was disputed by Cameroon $\mathbf{J}$ and more specifically by Froneman $\mathbf{J}$ with Van der Westhuizen $\mathrm{J}$ concurring in their dissenting judgements. ${ }^{65}$ Clearly expropriation can occur in only limited circumstances despite that investors' property would have been taken as per the definition appended to expropriation in South Africa. This is so because the state will not take property to acquire it but to pass it on to the historically disadvantaged persons and this will not amount to expropriation.

The criteria for compensation under the South African Constitution is not the same as the 'prompt, adequate and effect' compensation. The Constitution promises 'just and equitable'

\footnotetext{
${ }^{58}$ Reflect-All 1025 CC and Others v MEC for Public Transport, Roads and Works, Gauteng Provincial Government and Another 2009 (6) SA 391 (CC) [Reflect-All]

${ }^{59}$ Reflect All, para 64.

${ }^{60}$ Agri South Africa v Minister for Minerals and Energy 2013 (4) SA 1 (CC) [Agri SA], para 67. 61

${ }^{62}$ Compañía del Desarrollo de Santa Elena, S.A. v Republic of Costa Rica (2000) ICSID Case No.ARB/96/1, para 77; Starrett Housing Corporation, Starrett Systems, Inc, Starrett Housing International, Inc v The Government of the Islamic Republic of Iran, Bank Markazi Iran, Bank Omran, Bank Mellat Award December 19834 Iran-US - C.T.R. $122,154$.

${ }^{63} \mathrm{Id}$.

${ }^{64}$ Agri SA, para 68.

${ }^{65}$ Agri SA, paras $77-108$.
} 
compensation. It is notable that when awarding just and equitable compensation under the Constitution, the following factors need to be taken into account:

- The history of the acquisition and current use of property:

- The current use of property;

- The market value of property;

- The extent of direct state investment and subsidy in the acquisition and beneficial capital improvement of the property; and the purpose of expropriation.

In the Swiss investor case, if the case were to be adjudicated before the South African courts, the amount of compensation would have been much less given that the property was not in use.

\section{Dispute Settlement}

More than anything else, international arbitration has been the hallmark of investment regime; countries prefer international arbitration over host state national courts. Even countries such as South Africa which are not parties to the ICSID Convention have submitted to international arbitration at ICSID. Accordingly, almost all BITs especially early BITs have a clause on international arbitration; it is only in recent years as indicated above that some countries are beginning to take a step back from international arbitration as discussed above. South African BITs equally contain a clause on international arbitration; however, the Protection of Investment Act has taken slightly different route. Specifically, the Act creates mediation process, which can be facilitated by the Department of Trade and Industry; ${ }^{66}$ however, parties are not precluded from approaching any of the competent courts in South Africa. ${ }^{67}$ If after exhausting all the local remedies, a party is still not satisfied, South Africa may agree to international arbitration but which will take a form of state-to-state arbitration. ${ }^{68}$

Brazil, which never concluded any BITs, has now embarked a journey to enter into Partnership Agreements. Notably, the Brazilian Partnership Agreements do not have international arbitration on investor-state dispute settlement mechanism; rather, the Agreements have state-to-state dispute settlement although it will be used as a last resort as dispute prevention is a preferred route.

\section{MULTILATERAL INVESTMENT TREATY: HOW SHOULD IT LOOK LIKE}

\footnotetext{
${ }^{66}$ Protection of Investment Act, s 12(1) - (3).

${ }^{67}$ Protection of Investment Act, s 12(4).

${ }^{68}$ Protection of Investment Act, s 12(5).
} 
Why no multilateral treaty? Since the failed Havana Charter, there has not been a successful attempt for a multilateral treaty on investment - the OECD Multilateral Agreement on Investment (MAI) which was started in 1998 also failed. Notable about the failed OECD MAI is the fact that developing countries were primarily excluded as it was felt that their interest/demands would dilute the MAI. ${ }^{69}$ The reason for excluding developing countries is lamentable because despite great interest that developed countries have in investing in developing countries, the latter are never seen as partners in negotiations but rule-takers, and this has resulted in the world economic order not functioning optimally as it should; there is a persistent failed agreement after the other resulting from failure to recognize the needs of developing countries.

At the GATT/WTO level, the United States have, on several occasions, tried to push for a comprehensive agreement and was faced with a push back from developing countries. ${ }^{70}$ Specifically, during the Uruguay Round Negotiations, US and Japan argued that Articles 1, II, III, IV, XI, XV, XVI, XVII, XVIII and XXIII already addressed TRIMs but wanted a multilateral agreement that gives detailed regulation of TRIMs ${ }^{71}$ In addition to the views of the United States, Japan added that TRIMs inconsistent with the GATT should be eliminated, and other TRIMS related to GATT should be regulated to avoid distortion of comparative advantage. $^{72}$

EEC and Developing countries: drew distinction between investors and goods producers. Thus, they argued that it would be improper to broaden the scope of TRIMs to all areas if investment to go beyond those related to trade. Specifically, EEC indicated that only those related to trade such as local content, manufacturing, and export requirements can be brought to the realm of the GATT. ${ }^{73}$ Similar to EEC, developing countries were concerned but overreaching TRIMs, they wanted only trade related investment measures to be prohibited they felt that non-trade investment measures such as local equity requirements and investment incentives. ${ }^{74}$

When TRIMs was adopted, it reflected the position of EEC and developing countries in that only trade-related investment measures were regulated and specifically they were not to violate article III (national treatment) and XI (quantitative restrictions).

\footnotetext{
${ }^{69}$ Jurgen Kutz, 'A General Investment Agreement in the WTO? Lessons from Chapter 11 of NAFTA and the OECD Multilateral Agreement on Investment,' 23(4) U. Pa. J. Int'l Econ. L (2014) 713-789, 714.

${ }^{70}$ Jurgen Kutz, 'A General Investment Agreement in the WTO? Lessons from Chapter 11 of NAFTA and the OECD Multilateral Agreement on Investment,' 23(4) U. Pa. J. Int'l Econ. L (2014) 713-789, 724.

${ }^{71}$ Edmund M.A. Kwaw, Trade Related Investment Measures in the Uruguay Round: Towards a GATT For Investment? 16 N.C.J. INT'L L. \& COM. REG (1991) 309-349, 325.

${ }^{72}$ Edmund M.A. Kwaw, Trade Related Investment Measures in the Uruguay Round: Towards a GATT For Investment? 16 N.C.J. INT'L L. \& COM. REG (1991) 309-349, 327.

${ }^{73}$ Edmund M.A. Kwaw, Trade Related Investment Measures in the Uruguay Round: Towards a GATT For Investment? 16 N.C.J. INT'L L. \& COM. REG (1991) 309-349, 328.

${ }^{74}$ Edmund M.A. Kwaw, Trade Related Investment Measures in the Uruguay Round: Towards a GATT For Investment? 16 N.C.J. INT'L L. \& COM. REG (1991) 309-349,328-9.
} 
DOHA Ministerial Declaration indicated the desire to have an agreement on investment, ${ }^{75}$ but it also went down with the failed DOHA Round.

In 2000, one commentator argued that a multilateral agreement on investment was not yet ripe to be negotiated and emphasized that many more BITs have to be concluded and their benefits realized by both developed and developing countries. ${ }^{76}$ Well, more than enough BITs have been signed and their benefits have been realized by investors at the expense of host countries. In turn, developing countries reacted and the investment climate is now shaky. The time is therefore now to negotiate a multilateral treaty on investment which must take into account both the interest of both developed and developing countries. This section discusses the tenets of such a treaty.

\section{Purpose of the proposed treaty on investment}

Trade is concerned with the removal of barriers to international trade, and earlier proposal of a multilateral investment treaty suggested removing barriers for global investment. ${ }^{77}$ In fact, the purpose of all GATT7WTO Agreements is to create environment for comparative advantage through elimination of tariffs and non-tariff barriers. ${ }^{78}$ As it has been shown above, no country would be willing to liberalise its domestic market, and this on its own will be in sharp contrast with the spirit of the GATT/WTO. Rather, countries or investors are much more interested in predictability of the investment rules in host countries, and this should be the purpose of such a multilateral treaty. The markets must be allowed to drive liberalization of investment instead of multilateral treaty. It is tempting to think of imposing the WTO/GATT discipline (liberalization) on investment but this just cannot work.

Salacuse proposed that the World Bank, being an institution that houses both developed and developing countries, and also sensitive to development issues, should be a home to the General Agreement on Direct International Investment as he termed it. ${ }^{79}$ I however doubt that developing countries can still see the World Bank as an appropriate institution especially with its infamous ICSID Tribunal. ${ }^{80}$ Although the WTO will be an ideal entity, it unfortunately focuses on investment aspects that affect international trade as its mandate is on removal of trade barriers. Otherwise the United Nations Conference on Trade and Development

\footnotetext{
${ }^{75}$ WTO, Ministerial Declaration: Ministerial Conference Fourth Session Doha,WT/MIN(01)/DEC/1 20 (Nov. 14, 2001), 20-22.

${ }^{76}$ Riyaz Dattu, 'A Journey from Havana to Paris: The Fifty-Year Quest for the Elusive Multilateral Agreement on Investment' 24(1) Fordham International Law Journal (2000) 275-316, 277.

${ }^{77}$ Todd S. Shenkin, Trade-Related Measures in Bilateral Investment Treaties and the GATT: Moving Toward a Multilateral Investment Treaty 55 U. Pitt. L. Rev 541 (1994) 541-606, 544.

${ }_{78}$ John Jackson World Trade and the Law of the GATT (1969) 330.

79 Jeswald W. Salacuse, Towards a New Treaty Framework for Direct Foreign Investment 50 Journal of Air Law and Commerce (1985) 969-1010, 1006.

${ }^{80}$ The discontentment of developing countries about the World Bank is evidenced by alternative financial institutions that developing countries are establishing such as the BRICS Bank. The idea behind BRICS among others is to leverage the influence and hegemony that United States and other Western countries have on them as developing countries.
} 
(UNCTAD) will be ideal although it may have challenges when it comes to settlement of investment disputes.

2. Entry and establishment requirements

a) Right of entry and establishment

The multilateral treaty on investment should not create the right of entry and establishment, and this should left to states because only states can determine which areas need FDI for their economic developmental needs.

b) Investment Measures:

The discussion of why investment measures, especially performance requirements, are so undesirable for the global welfare is based on neo-classical theory on TRIMs which presupposes perfect competition in the global markets and therefore shuns any governmental intervention as that can only improperly allocate resources (inefficient allocation of resources). ${ }^{81}$ It is now trite that markets are imperfect and so is competition; therefore, the whole idea of performance requirements is to force development that is expected from FDI, ${ }^{82}$ yet the use of performance requirements is not without criticism as to whether they bring development or not in the host country. Specifically, the imposition of local content forces the firm to gets inputs from an otherwise expensive local supplier thereby pushing the prices of products up. Coupled with export requirements, it follows therefore that without export subsidies the firm cannot on its own sustain the exports at high prices to the world prices. ${ }^{83}$ To this effect, the state must then use taxes to subsidize the firm for exports. Given that the local firms would have been shielded from competition, the prices of inputs will decidedly go up. This narrative clearly does not point to development but a vicious circle of export subsidies and enrichment of a particular sector that supplies inputs to the foreign firm. On the other hand, performance requirements and incentives can find support in Japan-Korean Model, ${ }^{84}$ which drove the South Korea exports in electronics up. Interestingly though, the

\footnotetext{
${ }^{81}$ United Nations, The Impact of Trade-Related Investment Measures on Trade and Investment: Theory, Evidence and Policy Implications (United Nations, 1991) 32.

82 'Far from generating a favourable impact on income distribution and social development, their operations may support a small oligarchy of indigenous partners and suppliers. Their use of 'inappropriate' capital intensive technology may produce a small labour elite while consigning many workers to the ranks of the unemployed (or underemployed) if local labour market rigidities fail to deploy them to more productive occupations. Their tight control over technology, higher management functions, and export channels may prevent the beneficial spillovers and externalities hoped for in the more optimistic scenarios,' Theodore H. Moran Foreign Direct Investment and Development: The New Policy Agenda for Developing Countries and Economies in Transition (Institute for International Economics, 1998), 21.

${ }^{83}$ Theodore H. Moran Foreign Direct Investment and Development: The New Policy Agenda for Developing Countries and Economies in Transition (Institute for International Economics, 1998), 32.

${ }^{84}$ The Japan-Korean Model is characterized by imports restraints and export promotion, subsidies and grants to create national companies, restrictions on FDI coupled with requirement for licensing technology instead of establishing subsidiaries, see Theodore H. Moran Foreign Direct Investment and Development: The New Policy
} 
study undertaken by the United Nations on the Impact of TRIMs on Development indicates that the influence of TRIMs on firm behavior is relatively small, as such, TRIMs as a trade policy has a little impact on investment flows. ${ }^{85}$ Further, it is indicated in the same study that firms showed that TRIMs simply required them to implement operations they intended to do anyway, that is, building local supplier network or industry - TRIMs only accelerated seed within which the firm carries out its intended operations. ${ }^{86}$

Nevertheless, this paper is not about the economic benefits of performance requirements but on what the multilateral investment should entail in order to cater for the interests of both developing and developed countries because developing countries in keen on performance requirements while developed nations use incentives. In any event, like any policy, performance requirements can succeed or fail, and its failure or success is influenced by other factors:

'TRIM failures,..., were associated with sub-economic size of operation, subsidies to compensate investors for high-cost operations and shelter from competition. On the other hand, TRIM successes, ..., were associated with economic size (full utilization of economies of scale), subsidies aimed at facilitating corporate exit and adjustment and at compensating for initial risk and uncertainty, and subsequent exposure to competition in world markets. ${ }^{, 87}$

What has become evident is that host states, especially developing countries, cannot sit back and hope that firms or FDI can bring economic development, as it is supposed by expanding efficiency, pushing productivity outward and improving economic growth of the host state, without any interventions. Therefore, it is without doubt that neo-classical theory cannot be maintained; rather strategic trade theory must be deployed. As alluded to earlier, the strategic trade theory is premised on the realization of imperfect competition with barriers to trade, and therefore allows intervention to develop domestic industry. Strategic theory has largely been invoked by developed nations to shift production locations. ${ }^{88}$

Even with the performance requirements that are said to violate Article III and XI of the GATTA, perhaps TRIMs Agreement ignores the whole rationale why they are invoked by developing countries, and this therefore calls for the multilateral treaty that seeks to balance investment promotion with protection. As UNCTAD has aptly put it, it would be difficult if not impossible for developing countries to agree to dismantle TRIMs without corresponding

Agenda for Developing Countries and Economies in Transition (Institute for International Economics, 1998), $127-8$.

${ }^{85}$ United Nations, The Impact of Trade-Related Investment Measures on Trade and Investment: Theory, Evidence and Policy Implications (United Nations, 1991) 6.

${ }^{86}$ United Nations, The Impact of Trade-Related Investment Measures on Trade and Investment: Theory, Evidence and Policy Implications (United Nations, 1991) 6.

${ }^{87}$ United Nations, The Impact of Trade-Related Investment Measures on Trade and Investment: Theory, Evidence and Policy Implications (United Nations, 1991) 6.

${ }^{88}$ United Nations, The Impact of Trade-Related Investment Measures on Trade and Investment: Theory, Evidence and Policy Implications (United Nations, 1991) 33. 
agreement on the standards regulating conduct of investor, that is, investment liberalization must be accompanied with economic development. ${ }^{89}$

\section{Standard of protection}

Given that expropriations are no longer rife, the proposal put forward has been that if WTO were to adopt a multilateral agreement on investment, it should rather focus on the implementation of liberalized commitments instead of investment protection measures. ${ }^{90}$

a) National treatment and Most Favoured Nation

Quite to the contrary to the position adopted by India and South Africa, once the investment has been admitted, it should be given national treatment and MFN treatment. Perhaps, the reason why India and South Africa have adopted the route of severing MFN is because there is no multilateral treaty on investment, and therefore MFN creates free-riding, which yields detrimental results in the field of investment. Of course, exceptions to national treatment should be maintained on the basis of the strategic trade theory is premised on the realization of imperfect competition with barriers to trade, and therefore allows intervention to develop domestic industry through performance requirements. Therefore, national treatment and MFN standards must be applied post entry subject to fulfilling performance requirements. Strategic theory has largely been invoked by developed nations to shift production locations. ${ }^{91}$ There are arguments to allow countries to give a list of sectors they would like to liberalize in a multilateral treaty as it is done in trade but this model cannot work for investment because liberalizing sectors creates lasting obligations which cannot easily be changed even when economic conditions require so.

\section{b) Fair and equitable treatment}

The approach taken by India and South African should be adopted by the multilateral treaty. Thus, the vagueness of this standard coupled with the fact that national treatment (best treatment as opposed to 'greed treatment') and compensation are available; FET treatment standard can only bring chaos in the global economy. It is no use to rip countries off their limited resources under the guise of FET standards; it can only result in global economic and social ills that we are seeing by enriching a limited minority at the expense of populations.

\section{c) Full protection and security}

What is needed here is for the multilateral treaty to revive the basics, that is, to revert to customary international law on protection and security instead of 'full' protection - alien property must be protected by the host state as a matter of customary international law. ${ }^{92}$

\footnotetext{
${ }^{89}$ Revitalising Development Growth and International Trade: Assessment and Policy Options, Report to UNCTAD ViI at 157, UNCTAD TD/238/Rev. 1.

90 Jurgen Kutz, 'A General Investment Agreement in the WTO? Lessons from Chapter 11 of NAFTA and the OECD Multilateral Agreement on Investment,' 23(4) U. Pa. J. Int'l Econ. L (2014) 713-789, 780.

${ }^{91}$ United Nations, The Impact of Trade-Related Investment Measures on Trade and Investment: Theory, Evidence and Policy Implications (United Nations, 1991) 33.

${ }^{92}$ L'Affaire Goldenberg (Rumania v. Germany), 2 U.N.R.I.A.A. 901, 909 (1949). Respect for private property rights is an indispensable rule of all Jaw, national and international, for the right to private property is, generally speaking, essential to the well-being and development of all peoples. Rapporteur Huber puts this well in the
} 


\section{Expropriation and compensation}

As indicated above, the costs of regulating in the public interest have being very high. Consequently, the multilateral treaty on investment must undoubtedly respect host's right to regulate for public interest thereby upholding the international norm of state sovereignty. This right is often conflated with indirect expropriation as evidenced by cases in both NAFTA and ICSID tribunals where countries have been found to have expropriated investment, directly or indirectly, in their endeavor to regulate in the public interest. Surely foreign investment cannot trump over the most important feature of governments. Specifically in Metalclad v United Mexican States, the Tribunal found that the Ecological Decree that earmarked the contended site a Natural Area constituted an indirect expropriation in violation of Article $1110 .{ }^{93}$ Whether written down in constitutions or not, all governments have an inherent right to regulate yet when developing countries voice it out, they are found to be over protective and scarce foreign investors away as it happened in South Africa. As indicated above, this right is available in every polity including in blocks such as the European Union. To this end, Article 1 of the European Convention on Human Rights provides that -

"Every natural or legal person is entitled to the peaceful enjoyment of its possessions. No one should be deprived of his possessions except in the public interest and subject to the conditions provided for by the law and by the general principles of international law.

The proceeding provisions shall not, however, in any way impair the right of a state to enforce such laws as it deems necessary to control the use of property in accordance with the general interest or to secure the payment of taxes or other contributions or penalties"

Nevertheless, this essay cannot ignore the fact that investments are threatened under the guise of the government right to regulate. Specifically in extractible resources, often host state will agree on certain terms with a company, and the successive government would want to change those terms on the grounds that they were generally onerous and did not cater for the national needs. As Moran puts it, 'all successive governments have done it, left-wing governments engaged in it and so did right-wing governments; democratically elected governments engaged in it and so did authoritarian governments; civilian governments engaged in it and so did military governments.' Unlike in other sectors, the mineral and infrastructure sectors cannot threaten to divest because of the huge capital they would have invested, 'they do not have rapidly changing technology, proprietary processes...to without in resisting

British Claims in the Spanish Zone of Morocco (Great Britain v. Spain) Arbitration, 2 U.N.R.I.A.A. 615, 641 (1949):

${ }^{93}$ Metalclad v United Mexican States 
renegotiation of their contracts. ${ }^{94}$ To this end, investors must still get protection and therefore the South African approach pertaining to expropriation and deprivation of property cannot be maintained in the multilateral treaty. Kutz proposed that compensation should be limited to direct expropriation and not be extended to indirect or creeping expropriations, ${ }^{95}$ but this would be quite an onerous proposal given how bad creeping expropriations sometimes affect economic value of investment. Nevertheless, this idea would need to be given closer attention because creeping expropriations are more prevalent than direct expropriations.

With regard to compensation, the 'prompt, adequate and effective' compensation standard is just too high to be maintained in the multilateral treaty. Rather, states must consider 'appropriate compensation . . . taking into account . . all circumstances that the State considers pertinent ${ }^{96}$ or 'just compensation. ${ }^{, 97}$ Further, states must consider flexible ways in which payment can be made because often the issue of affordability and available of foreign currency is real for developing countries. The UK BITs in this regard are commendable for the flexibility they have adopted in effecting payment. In addition, for predictability purposes, the multilateral treaty should give time-lines within which payment should be made.

\section{Dispute settlement}

It is a long standing rule of customary international that aliens are given the same treatment as nationals and be subjected to national laws, ${ }^{98}$ yet developing countries seeking to attract FDI bound themselves to a higher standard of treatment as against national treatment with regard to dispute settlement. Thus national investors were subjected to national courts whereas foreign investors had the right to resort to international arbitration using treaty law instead of national law.

Two issues arise here: national treatment and international arbitration. First, the trend seems to be that states are going back to state-to-state arbitration, and this will be unsuitable for investment as opposed to trade because with investment, we are talking here of investments that are taken in the event of expropriation yet it is well known that states do not always want to litigate; they take into account many factors to decide whether to litigate or not. Should the home state decide not to litigate, then we are talking of loss of property and unjustified enrichment. State-to-state is totally unsuitable for investment cases. On the other hand, given the trends in investment tribunals, states are increasingly showing reluctance to agree to

\footnotetext{
${ }^{94}$ Theodore H. Moran Foreign Direct Investment and Development: The New Policy Agenda for Developing Countries and Economies in Transition (Institute for International Economics, 1998), 143.

95 Jurgen Kutz, 'A General Investment Agreement in the WTO? Lessons from Chapter 11 of NAFTA and the OECD Multilateral Agreement on Investment,' 23(4) U. Pa. J. Int'l Econ. L (2014) 713-789, 786.

${ }^{96}$ Report of the Second Committee, U.N. Doc. A/9946 Dec. 9, 1974, and G.A.Res. 3281, 29 U.N. Doc. GAOR Supp. (No. 31) 50, U.N. Doc. A/9631 (1974), reprinted in, 14 Int'l Legal Mat. 251 (1975).

${ }_{97}$ Norwegian Shipowners Claims (Norway v. United States)

98 Czechoslovak Agrarian Reform (German Subjects) case, Czechoslovakia, 1925, McNair \& Lauterpacht, Annual Dig., 1925-1926, Case No. 98.
} 
investor-state. It follows therefore that the most viable option would be for the multilateral treaty to adopt the South African approach - using local courts and resort to international arbitration using state-to.-state. This is largely so because in some jurisdictions such as South Africa, courts work efficiently and there is no executive influence. What is obvious is that states are not going back to investor-state.

Assuming the WTO becomes a chosen forum for investment treaty, there were proposals already to create private rights in the GATT system in order for individual corporates to be able to litigate investment disputes in the GATT Dispute Settlement Body. ${ }^{99}$ To this effect, WTO members guard jealously against this institution and it is far-fetched that they can agree to create private rights thereby enabling investor-state dispute settlement. In any event, the proposals on the reform of the WTO Dispute Settlement on the Doha Agenda are only limited to clarification on consultations. ${ }^{100}$ The challenges that host states faced regarding their normal government regulation being questioned and be found to be indirect expropriation will be issues of the past once investment agreement with state-to-state is established in the WTO but the loses to the investors will be unimaginable.

\section{CONCLUSION}

With the move away from the BITs that has been described above to national regulation of investment, it is compelling that a multilateral treaty should be adopted. This is especially so because whereas it may be argued that investments will still be given adequate protection under national law, it is no joke that governments are not static and so the change in governments carries with it the change in the standards of protection that exist under domestic law. On the other hand, international law is akin to predictability and not prone to swift changes that are not desirable for investment especially in extractible resources as they demand long investment periods. Also, international treaties carry with them an inherent obligation on state to carry its treaty obligations in good faith - pacta sund servanda, which does not exist at national law. This treaty will be beneficial to both developing and developed countries because individually developing countries are not able to resist the pressures exerted on them by developed nations as evidenced by the provisions of BITs which are in sharp contrast with their position as developing countries pronounced under CERDs. Similarly, capital exporting countries need certainty which they cannot get through national laws of developing countries. Interesting, some of developing countries which need FDI are also capital-exporting countries - for example, South Africa, Brazil, and India and they would undoubtedly not want to get adverse effects of national regulation of FDI in host countries.

\footnotetext{
${ }^{99}$ Todd S. Shenkin, Trade-Related Measures in Bilateral Investment Treaties and the GATT: Moving Toward a Multilateral Investment Treaty 55 U. Pitt. L. Rev 541 (1994) 541-606, 544.

${ }^{100}$ WTO, Ministerial Declaration: Ministerial Conference Fourth Session Doha, WT/MIN(01)/DEC/1 20 (Nov. 14, 2001), 22.
} 
On the basis of the proposal made above, the question to be asked is: Has developing countries re-written the rules?

'The new literature is a frustrating reminder to the South that too often ideas become intellectually respectable only when they become congruent with the interests of major Northern countries. Hence it is more than a little ironic that the new trade theory has developed against the backdrop of trade conflicts among developed countries, and between United States and Japan, in particular. ${ }^{, 101}$

\footnotetext{
101 Dani Rodrik, 'Imperfect Competition, Scale Economies and Trade Policy in Developing Countries,' in
} Robert Baldwin (ed), Trade Policy Issues and Empirical Analysis (Chicago University Press, 1988) 109. 